\title{
FROM QUEBEC TO BRAZIL: TRANSLATION AS A FRUITFUL DIALOGUE BETWEEN “AMÉRICANITÉ" AND "AMERICANIDADE"
}

\author{
Marc Charron \\ University of Ottawa \\ marc.charron@uottawa.ca \\ Luise von Flotow \\ University of Ottawa \\ lvonflotow@gmail.com
}

\begin{abstract}
Américanité" as a concept developed and refined by literary scholars to address a certain Québécois interest in writing and film, is paralleled here by the Brazilian concept "americanidade." Both evoke the "americanness" of contemporary writing in the Americas, and imply a turning away from European models and requirements toward a hybridization and a focus on movement, inter-relations, trans-cultural contacts. Translation, by definition a transcultural activity, moves these "american" texts from one language to another. In this article we study the translation of an archetypical novel of Quebec "américanité", Jacques Godbout's Une histoire américaine (1986) into Brazilian Portuguese. We examine the concepts of américanité and americanidade and hypothesize that such shared americanness will aid in the translation, or at least be recognized as the text moves from French to Portuguese. We examine the outcome of the translation from this particular perspective, and conclude that Europe in fact still intervenes as the major reference.
\end{abstract}

Keywords: translation studies, Quebec literature and américanité, Brazilian americanidade. 


\section{Introduction}

The question of identity has perhaps been the most important theme in Quebec literary studies since the 1960s, coinciding with both a break from French literary models and the territorialization (i.e. from French Canadian to Québécois) of nationalist discourse. And while French work from Quebec may seem less and less part of Canadian literature - the institutionalization of Quebec literature in the 1960s has supported this view -, the question of its possible "américanité" ${ }^{1}$ has been central since the 1970s, peaking in the late 1980s with Denys Arcand's internationally acclaimed and influential film Le Déclin de l'Empire américain in 1986. In this environment, the notion of Quebec's "américanité" has seldom been associated with anything else than the culture's possible, and often confrontational, relationship with the American/USA experience. But this trend has given way to a more continental interpretation of "américanité," especially since the late 1980s with the work of Zilá Bernd, Gérard Bouchard and Yvan Lamonde, and also of others scholars in Quebec literary studies. ${ }^{2}$

In the discourse of Brazilian scholars such as Bernd, who works in close touch with Quebec literature, a similar concept has developed around contemporary Brazilian literature, where brasilidade, the label for Brazilian national(ist) writing, largely discussed in recent years in terms of Oswald de Andrade's 1928 Manifesto Antropófago seems to have been taking a more continental turn as well: "Sem dúvida, os postulados da Antropofagia prefiguram-se como emergência do que hoje estamos chamando de americanidade, ao preconizar uma identificação distintiva ao continente americano."(Bernd 2008) Indeed, there seems to be a shared impetus between Québécois and Brazilian literary scholars to promote what Bernd has termed americanidade compartilhada and even referred to as "américanité de la francophonie" a term first proposed in another context altogether by Nicolas Van Schendel. ${ }^{3}$

Bernd recognizes the perhaps excessive ambition of working with such a shared concept across two continents, in fact, across 
an entire hemisphere - an immense area that is so tremendously diverse and heterogeneous, and where the development of an "american" 4 identity would require a break not only with all the other histories but also with ethnic points of reference as well as linguistic, cultural, political and national traditions. And yet, she insists that the 'alterity' inherent in this concept can be useful to express the "non-location," the "migrancy," the hybridity of "american" populations in constant mobility:

\begin{abstract}
A grande vantagem é que a noção de americanidade - com suas variantes

"américanité" e "americanidad" - obriga a introduzir a dimensão da

alteridade na reflexão sobre o identitário, podendo se constituir como

uma espécie de não-lugar identitário para as populações migrantes.
\end{abstract}

In this paper we explore how and to what extent the notion of "américanité" in Quebec literature has travelled to Brazil, through translation and appropriation, and we suggest that Brazil's own selfidentification with "americanidade" might aid in this movement.

We refer mainly to Jacques Godbout's Une histoire américaine (hereafter $U H A$ when referring to the French original), which appeared in 1986, the same year as Arcand's Le déclin, and examine its translation into Brazil in 1999. ${ }^{5}$

Our focus is on the translatability of this work's "américanité" into a culture overlaid with its own "americanidade." This perspective is influenced by the direction taken by Edwin Gentzler in Translation and Identity in the Americas (2008), which shows how the understanding of cultural identity is central to the processes and products of translation in the Americas. Ultimately, we ask whether the notion of "american identity", if it does exist, is necessarily a translated and translatable one. 


\section{The American(ized) Quebec Novel of the 1980s}

There seems to be a consensus among scholars who have worked on this topic that certain Quebec novels clearly require the label of "américanité". Besides Godbout's UHA of 1986, the most important are Jacques Poulin's Volkswagen Blues $(1984)^{6}$ and Monique LaRue's Copies conformes (1989)7. All three focus and are translational comments on California. Poulin's Volkswagen Blues is often described as a "road novel" that retells/retravels the history of the French explorations of North America as well as engaging with another, indigenous, history of the Americas to finally end up in San Francisco. LaRue's book tells the story of the search for lost computerized information in the emergent California computer culture of the mid-1980s, and as critic Daniel Canty writes, poses a series of existential questions on "american" hybridity in the form of " l'hybridation identitaire des personnages et de leur environnement " [ «the hybridization of characters» identities and environments»]. Godbout's $U H A$, as suggested in note 3, tracks the flight of the one-time academic turned Quebec politician Grégory Francoeur to California, and his failure there, as he gets enmeshed in the (political) smuggling of illegal immigrants, and ends up accused of rape and arson: the book consists in large part of the story Francoeur is asked to write in his defense.

What can explain the publication of three important novels of "américanité" in Quebec literature in a period of just 5 years, along with the Arcand film of 1986? For one, it is well-known that after the Referendum on Quebec sovereignty in 1980 (in which the "No" side won with nearly $60 \%$ of the vote), many Quebec nationalist intellectuals looked outside of the province and also of Canada, and especially into the direction of the US. If they did not go in search of answers to the question of politically "unresolved" Québécois identity, they were perhaps looking for a space where this same "identity" might become "alterity", a position from which to reflect, among other things, upon what many have considered a socio-political oeuvre inachévée. America (and, more specifically, 
California) offered a convenient location both for these writers/ protagonists to search for answers after a period of introspective literary discourse, and to simply escape it all. All three books stimulate their readers to ask what might make up the "american alterity" of Quebec identity and how it might be possible to imagine and speak of an "américanité québécoise".

Now, if these are Quebec novels in which "américanité" is a particular trait $^{8}$, what does that mean for their translation? Does this quality make it easier for them to travel to the other parts of the Americas? And if so, what is retained of this "américanité québécoise"? Is it preserved in translation? Does it blend in with or resist other possible forms of "américanité" (be it EnglishCanadian americanness, Spanish-American americanidad, or Brazilian americanidade)?

\section{Américanité vs américanisation}

Before we examine the translatability of "américanité" into other parts of the Americas, we need to ask what the term refers to specifically in Quebec. While it has, at times, been criticized for being too loose a concept, more recent studies, especially those of the past decade, tend to consider it as fully "operational" First, various literary scholars and social scientists (Dupont 1991, Guillemette 2000, and Morency 2004) note that the difference between "américanisation" and "américanité" is often criticized for being unclear, with "américanisation" until recently being thought of almost exclusively in negative terms. But, in an effort to distinguish the two concepts, Jean Morency (2004) suggests that "américanisation" ought to be considered as the «influences exercées par la culture états-unienne, que ces influences soient négatives ou positives, subis ou voulues »(p. 42-43) [tr. Americanization should be theorized in terms of the influences wrought by the culture of the USA, whether these be negative or positive], while "américanité" ought to be considered as « les confluences de nature 
symbolique qui caractérisent les cultures en terre d'Amérique » (ibid.) [the symbolic confluences that characterize the cultures of the Americas.]

In making this distinction, Morency follows Bernd (2008) who insists that: "A americanidade não se confunde com americanização (asumir o "American way of life"), pois remete - ao contrário - à insearção de um dialogismo, como oposição ao "consenso globalizante da anglofonia." For Bernd, "americanidade"/"américanité" involve not only "dialogue" but also "opposition to the globalizing consensus imposed by English" - i.e. she adds Brazilian and French to the mix that is America.

Morency agrees that it is difficult to clearly differenciate the two notions (p. 43), because, as he says, " les deux phénomènes se présent[e]nt comme deux ensembles qui se recoupent, du moins en partie " [the two phenomena are seen as two overlapping aspects of the same thing]. But, perhaps most importantly from our perspective, he adds:

Dans la zone d'intersection que délimite la rencontre de ces deux ensembles, on se trouve en présence [...] de certains phénomènes de nature interculturelle, qui servent d'interfaces, c'est-à-dire de points de rencontre concrets entre les cultures: influences assumées et reconnues, transferts interculturels, usages intertextuels et interdiscursifs, activités de traduction et d'adaptation, ainsi que divers pratiques de création caractérisées par les emprunts et l'invention de formes hybrides. On le sait, l'étude de ces interfaces s'avère une part essentielle des nouvelles méthodes de l'analyse comparée, et il me semble qu'on devrait y accorder une attention particulière dans les études consacrées tant à l'américanité qu'à l'américanisation. (ibid.)

[In the intersections where these two concepts meet, we are in the presence of $[\ldots]$ intercultural phenomena, i.e. points where cultures really meet: where influences are accepted 
and recognized, and intercultural transfers, intertextual and interdiscursive usages occur, where translation and adaptation as well as any number of other creative practices take place that are characterized by borrowings and the invention of hybrid forms. We know that these interfaces play essential roles in new methods of comparative analysis and I believe that special attention should be accorded to studies of both "américanité" and "américanisation."]

Bernd (1986) had already reached this conclusion on the creation of hybrid forms as a sign of "americanidade": "c'est sous le signe de l>hybridisation [que] vont se construire les littératures des Amériques : d cune part la présence de l’héritage européen et d`autre part la désacralisation de cette culture et le dessein de recréer d autres mythes - américains - sur lesquels pourra être fondée une littérature authentique ». ${ }^{10}$ [The literatures of the Americas are constructed under the sign/influence of hybridization, with the European heritage very present on the one hand, and this same heritage being criticized and undermined, on the other - with the purpose of creating other myths - american ones - on which an authentic literature might be founded.]

One undeniable feature of "américanité" in contemporary Quebec literature then, and especially in the novel of the 1980s, is its "interculture," its hybridization - and perhaps its impulse to indeed "create other american myths" - of mobility, travel, available space, change but also danger and unbridled authority - as in Godbout's text. In this article, we set out to find out if the translation of Godbout's $U H A$ is one of these points de rencontre concrets entre les cultures.

\section{$U H A$ in Portuguese translation}

Of the three major "romans de l'américanité" of the 1980s, $U H A$ is the only one that was translated into Portuguese ${ }^{11}$. It is also 
one of the few works of Quebec literature translated ONLY into Portuguese (besides English). Uma história americana appeared in 1999, 13 years after the French original and 11 years after the English translation. The book was published by São Paulo's Nova Alexandria, a publishing house founded in 1992, which has a dozen series (from youth literature to gastronomy to literary studies). Uma história americana appeared as part of the "Literatura Estrangeira Contemporânea" series, which also lists translations of one novel by renowned Italian author Carlo Emilio Gadda and two by Nobel laureate William Golding. UHA is the second of only 7 books published over a 20 -year old period.

Uma história americana is the work of Samira Lunes, who is well-known for her contribution to foreign language teaching and the "Falar, ler, escrever português" didactic method which she co-authored with Emma Ebberlein O.F. Lima. UHA's cover design (discussed in detail below) is the work of Antonio Kehl, an illustrator who has done at least one other work for Nova Alexandria, including the cover of A Guerra dos Mundos, the Brazilian-Portuguese version of H.G. Wells's The War of the Worlds. The translation received a grant from the International Translation Grants program of the Canada Council for the Arts. In other words, and to sum up the production information around this book and its versions, Godbout's Une histoire américaine was subsidized at the outset by Canadian cultural funds which supported its writing; its translation into Portuguese (but strangely enough not in English, it seems) was supported by similar Canadian funds; in Brazil it appeared in a series designed for "emerging" international authors that seems rather disparate and unfocused, in a publishing house that has many other more important interests, and it was translated by someone who is not exactly a specialist of Quebec writing. The publication of $U H A$ in Portuguese is thus hardly an exceptional event; it seems almost accidental.

Still, the significance of the book, in terms of the overall situation of Quebec literature in Brazilian-Portuguese, is of interest: 
as of 1999, only three other books of fiction (all novels) had been translated from French into Portuguese in Brazil: Anne Hébert's Kamouraska ou A Máscara da Inocência in 1972 and her Os gansos selvagens de Bassan in 1986, Gérard Étienne's Uma mulher calada in 1987. At the time of publication of Uma história americana, there had not been a Brazilian translation of a Québécois or FrenchCanadian fictional work in over 12 years. Was its translation an attempt to bring Quebec "américanité" into contact with Brazilian "americanidade", and can it serve to exemplify Bernd's notion of "americanidade compartilhada"?

\section{The paratextual and intertextual elements of the Brazilian translation}

As has been shown in numerous studies of translations, the presentation of a translation, including cover, paratexts and translator's notes can give some idea of how the book is perceived and how it is marketed in the target culture: in the case of Godbout's $U H A$ these aspects are worth examining:

\section{Original cover}

The original French cover (fig. 1) is more Californian than American, especially with the palm trees and the siding of what looks like a seaside-type Northern California clapboard house; but the picture of the house and small red-brick building (a store?) next to it show no windows, and the palm trees (seen only in part) look like they might actually be enclosed in a space behind the two, which evokes the description of the planting of the palm tree in the prison yard - where Francoeur finds himself after having been arrested for, allegedly, both rape and arson - in the opening paragraph of the novel. 
The most striking element of the cover of the BrazilianPortuguese translation (fig. 2) is the image of the American flag, waving in the breeze; the rest of it, in black, shows three "sérienoir" type figures (none of which logically refer to any of the novel's main characters) and a hand holding a gun.

While the Quebec cover sharply contrasts the tall palm trees with the windowless buildings, thus offering a comment of sorts on the open yet claustrophobic Californian situation described in the book, the Brazilian cover clearly draws attention to the greatest of American symbols, and then to its film culture - not to the political thrillers of the past decades, but to its old Hollywood detective movies of the 1940s and 1950s, referring to the intrigue of the detective novel as a genre in its most classic form. ${ }^{12}$

\section{Back cover blurbs}

Again here, the texts that appear on the French original back cover and the Brazilian translation are very different. However, they are consistent with the respective covers of the books. The blurb in French refers to the main protagonist, Grégory Francoeur, as a "professeur québécois" [a professor from Quebec] who leaves behind him "à Montréal, famille et carrière politique" [ a family and a political career in Montreal] to become the assistant of an "éminent universitaire de San Francisco" [eminent academic in San Francisco] in the hope of starting his life again amidst "la tumultueuse luxuriance de la côte ouest des États-Unis" [the tumultuous luxuriance of the west coast of the USA]. The blurb ends by asking the indirect question: "Le miracle californien? La démence plutôt. D'emblée." [The miracle of California? More like its madness. From the very start.]

The back cover blurb of the Brazilian translation refers to Francoeur who "saiu do Canadá e foi para uma universidade na California"; it also refers to the author as "o premiado escritor e cineasta canadense" and to the main subject of the novel as 
"a intolerância e a violência da sociedade norte-americana" and speaks about a narrative account of the "drama verdadeiro contido no sonho americano".

It differs substantially from the original version by citing "Canada" (which appears nowhere in the French) and "(North) American society" 13 as a whole (only California as a geographical reference appears in French), and "the American dream" (the French expression " miracle californien » is more of a socio-economic reference, which evokes Silicon Valley and the fascination with electronic media culture). Further, the text in Portuguese makes no reference to Quebec but mentions Canada twice; it raises issues of social strife in US society usually linked to the larger problems of racism and poverty, and finally claims that the novel is a tale about the real, dark side of the American dream.

In the presentation of the back cover blurbs, we can thus observe a shift away from the elements that pertain to the novel's "américanité": the personal and political reasons why the protagonist leaves Montreal for California after the Referendum on Quebec sovereignty of 1980, the exuberance and excess of Californian aesthetics, the search not for the American dream but for the West as the "last frontier." Instead, we have a shift toward ideas that belong to the more traditional discourse of "américanisation," with its racial discrimination and gun culture, the other, darker side of what Bernd labels, in her definition of americanizaçāo, the "American way of life".

\section{Prefaces and footnotes}

Translators' prefaces and footnotes can help determine the extent to which the translator qua agent of intercultural transfer directly intervenes in the interpretation of the translated text, where the translator is on her own and most visible, and where the personal, extra-textual, editorial contribution of the translator is the leastmediated. ${ }^{14}$ 
In the case of Uma historia americana, there is no preface of any kind but the book includes 14 footnotes. In comparison, the French original contains no notes. In the Brazilian version, 8 of the 14 footnotes appear in the first chapter alone. And while the second note (on page 2) concerns the murder of Sharon Tate by Charles Manson, many of the other 13 footnotes deal with either intertextual traces within the French text (i.e. the first note addresses an allusion to a Verlaine poem and appears on page 1 ; note 6 explains a reference to a Baudelaire poem on page 11, while notes 4 and 8 explain aspects of Quebec cultural and political history, erroneously. Because of their location - in Chapter 1 - these notes play a considerable role in shaping and consolidating the Brazilian readers' perceptions of Quebec identity. The specific references to "French" literary intertexts deflect the focus from the representation of the North/South dichotomy ${ }^{15}$ (i.e. the Quebec/California) to a focus on Europe. While there are various intertextual traces in the Quebec original, the Brazilian footnotes primarily concern poetry of $19^{\text {th }}$ century France.

\section{Foreign graphic markers}

Although they are not strictly speaking para-textual elements, the presence of foreign-language words or expressions in any work of fiction serve to remind the reader of linguistic and cultural difference. This factor, always problematic to the translator, can be an indication of the level of linguistic and cultural hybridization in a given culture. Set mainly in English-speaking California, $U H A$ uses both English and Spanish terms in the predominantly French text, which of course, affects the visual and material aspect of the text; the linguistic alterity of other languages of the Americas (here English and Spanish) thus becomes a factor, even more so when concentrated in the limited space of a short paragraph.

For example, in the first paragraph of the last chapter, a motel called La Reina de Los Angeles de Porciuncula and the 
words coffee shops and waitress are kept in English and Spanish, and marked with italics in the French and Brazilian versions. Because of the socio-economic connotations associated with the terms "motel, coffee shops, waitress", this marking carries some discursive weight, inevitably drawing attention to at least some form of "américanisation." The French original and the Brazilian translation thus constantly direct the reader's attention to these foreign markers (usually with the use of italics). Interestingly, this makes the Brazilian translation a text composed of the four main languages of the Americas and, if only for that reason, a linguistically complete American work. This is a phenomenon that studies of literary "américanité" cannot ignore.

\section{Concluding remarks}

In conclusion, it could be said that the Brazilian reader of Uma história americana is offered a partially de-Americanized work, with the translator's footnotes playing the most important role in re-targeting this narrative, making it difficult for the story to leave Quebec, and constantly bringing readers back to either Quebec history (even at times its folklore) or its European cultural and literary influences (namely French poetry of the $19^{\text {th }}$ century), which are then transported to the "United States of America" and its brandished flag. Either the targeted Brazilian reader of 1999 was deemed to be too unfamiliar with Quebec history ${ }^{16}$ or, as we believe, thought to be more drawn to the aspects of "américanisation" than to those of "américanité".

The translation does not, in fact, do much to promote a possible confluence of Godbout's/Quebec's “américanité" with Brazilian notions of "americanidade". The intercultural dialogue between Quebec of the 1980s and, in this case, California - expressing both a fascination with but also a resistance to America - is not brought out by the translation, or aligned with a similar Brazilian dialogue. The "symbolic confluence that characterizes the cultures 
of the Americas", as described and theorized by Morency, is not at all obvious here. While Brazil's own americanidade might aid in translating such a book, and initiate an intercultural dialogue with Quebec's "américanité," the paratexts play a large role in shifting the text away from any such dialogue, too often choosing to either Europeanize or mark the Québécois as a "Non-American Other."

Perhaps a last glaring illustration of this tendency can be seen in the following example: Godbout's protagonist uses the expression "fuir le pays glacé des tuques et des goupillons" to describe his motivation to move to California. This is an allusion to another expression originally coined by Paul-Emile Borduas of the Refus global movement in 1940s Quebec: "Au diable la tuque et le goupillon!" Borduas was speaking from an anti-clerical, anti-nationalist, anti-traditionalist perspective, an attitude that Godbout's character takes up ironically in the 1986 novel. The Brazilian translation, however, does not explain this reference as an intertextual allusion to Borduas and Borduas' forward-looking politics; instead, it gives it a direct, unmediated, historical truthvalue: O Quebec, no dizer dos seus habitantes, é "le pays des tuques et du goupillon" - alusāo a origem camponesa da maior parte da populaçāo e a forte influencia religiosa". This expression has never constituted a popular saying in Quebec, and its use to explain Quebec society is an aberration. It has the effect of further dismantling the critical "américanite" of Godbout's text, and unwittingly returning it to roots in the 'exotic' yet docile Quebec Catholic peasant culture of the $19^{\text {th }}$ century.

If translation is to create and foster some "americanidade compartilhada" or any other type of "Inter-American" understanding, it needs to both acknowledge and mediate the "américanité" of the source work, and recognize it as a factor in the target culture. This has not happened with the version of Godbout's text offered to the Brazilian readership. Has it happened elsewhere, perhaps with non-fiction texts from Quebec, which Brazil has translated in large numbers? Perhaps a more important question is whether this shared "américanité" is even a topic for 
discussion when books, especially works of fiction, are selected for translation and translations are undertaken. This may be a wise step to take in the direction of a truly fruitful 'american' dialogue.

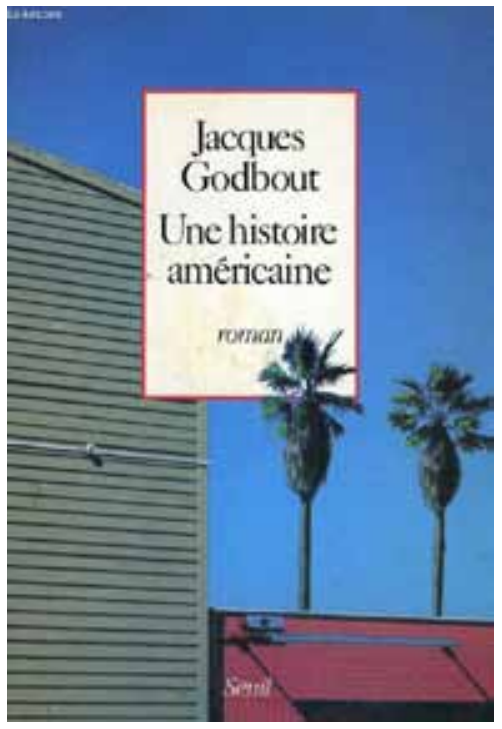

Fig.1

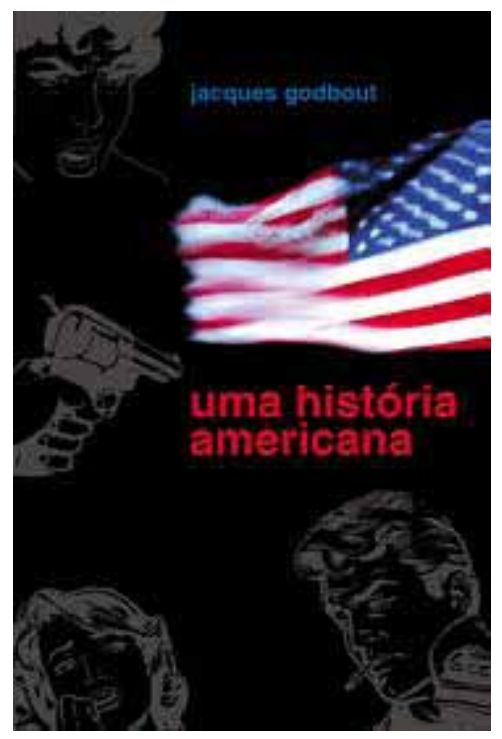

Fig. 2

\section{Notes}

1. Or "americannness" as it is at times referred to in English, although the term is not really used as such int the English-speaking world in general, and even less so in the US. Zilá Bernd writes: "É interessante notar que nāo há um equivalente em inglês para esta palavra, o que nos leva a crer que o ideologema nāo circula - ou ao menos nāo com este rótulo - no contexto anglófono.” The text from which this quote is taken can be accessed on the Web at http://partnership.files. 
wordpress.com/2008/02/americanidade-e-americanizacao.pdf. We will refer to it here as Bernd (2008).

2. Jean Morency's article «L'américanité et l'américanisation du roman québécois: réflexions conceptuelles et perspectives littéraires » (2004) provides an account of how the notion has developed since the 1960s, at least in the discourse of scholars of the Quebec novel.

3. Nicolas Van Schendel, «Une américanité de la francophonie? Les perceptions des migrants québécois » in Donald Cuccioletta (ed.). L'Américanité et les Amériques. Québec: Presses de l’Université Laval, 2001. p. 193-224.

4. Which we write here with lower case initial "a" to avoid confusion with "American" = of or from the US.

5. Like many of Jacques Godbout's novels, UHA appeared at Les Éditions du Seuil, a year before the major Paris publisher began doing most of Quebec literary works with Montréal's les Éditions du Boréal in co-edition. UHA was first translated into English in 1988 by Yves St-Pierre, an English literature teacher at Dawson College in Montreal. While the copyright page of the book in English specifies that the work was simultaneously published in Canada by Fitzhenry and Whiteside (a rather modest publishing house that has very few titles in fiction) and in the US by the University of Minnesota Press, every library catalogue and bibliographical entry refers to the American edition only. Could this, one might tempted to ask, make it even more "American" The book was not translated into Spanish - not in Spain, nor in Spanish-speaking America. As far as we know, there are no reviews of $U H A$ in Portuguese, and only one in English, which appeared in Publishers Weekly when St-Pierre's translation came out in 1988 and included this comment: "Famine in Ethiopia, illegal American intervention in Nicaragua, activists assassinated by the FBI, only politically "correct" issues are examined in this unsubtle novel by a leading Quebecois writer. Gregory Francoeur, a Canadian scholar who has come to Berkeley to undertake a study of happiness, has been, by the outset of this story, jailed on trumped-up charges and advised by the prosecutor to write down his version of the events leading to his arrest. Journal entries are interspersed with descriptive passages in a fashion that is more disruptive than suspenseful, a problem compounded by the curiously leaden quality of the prose: "'Is prison writing,' he wondered, 'always escapist literature?'" Leaving little to possible misinterpretation, Godbout's characters bear blatantly symbolic names: Allan Hunger aids Third World causes; Francoeur (Openhearted) almost reflexively embraces the underdog. The simplistic struggling of good guys 
against bad guys will fail to satisfy the reader." Interestingly, Copies conformes is a novel (of the espionnage genre that makes constant references - and offers a translational reading of sorts? - to Dashiell Hammet's The Maltese Falcon) that is set in San Francisco around a protagonist, Claire Dubé, whose husband must return to Montreal for a funeral and who stays behind in California to search for a lost circuit board containing the data to an automated translation software created by her husband.

6. Volkswagen Blues was published in Spanish translation in both Spain, by Random House Mondadori, and in Mexico, by Editorial Grijalbo - a Mexican subsidiary of the former -, and translated by Mexican translator Antonio Marquet in 2003; the book also appeared in Arabic, Czech, and Italian.

7. Interestingly, Copies conformes is a novel (of the espionnage genre that makes constant references - and offers a intertextual, translational reading of sorts - to Dashiell Hammet's The Maltese Falcon) that is set in San Francisco around a protagonist, Claire Dubé, whose husband must return to Montreal for a funeral and who stays in California because she must find a lost circuit board containing the data to an automated translation software created by her husband.

8. The word is also used by the publisher itself in the presentation page of the pocket book edition published in 1995 .

9. For example, Lucie Guillemette has written: «Tantôt décrié, tantôt encensé, le concept de l'américanité s'avère somme toute opératoire compte tenu de la pléthore de romans abordant des problématiques liées à des éléments d'inspiration américaine. » (2000 : 57) [The concept of 'americanness', which has been criticized and praised both, turns out, on the whole, to be quite functional, especially in regard to the large number of novels that deal with themes drawn from or inspired by american topics.]

10. Zilá Bernd, "La quête d)identité. Une aventure ambiguë », Voix et images, vol. XII, $n^{\circ} 1$, p. 21.

11. UHA was first translated into English in 1988 by Yves St-Pierre, an English literature teacher at Dawson College in Montreal. While the copyright page of the book in English specifies that the work was simultaneously published in Canada by Fitzhenry and Whiteside (a rather modest publishing house that has very few 
titles in fiction) and in the US by the University of Minnesota Press, every library catalogue and bibliographical entry refers to the American edition only. Could this, one might tempted to ask, make it even more "American"?

12. The cover of the American edition of An American Story (fig. 3) is in this sense neutral, as it represents the thematic layout of every book of the "Emergent Literatures" series at the UMP.

13. Literally "North American" society but basically understood as "American" society, that is, in very few circumstances is the term ever also associated with Canada, or even Mexico for that matter.

14. Even though a translator's footnotes are not clearly marked as personal interventions, they specifically reflect the translator's work, if only because many of them refer to language-related issues.

15. Geographer Louis Dupont includes this feature in what he considers possible dichotomies in discussions on "américanité".

16. Which, it could be argued, is not ultimately essential in this case. For example, Jean-Marie Klinkenberg (1987)has suggested that the novel is more about the narrator's narcissism than anything else.

\section{Bibliography}

BERND, Z. (1986), "La quête d'identité. Une aventure ambiguë", Voix et images, vol. 12, $\mathrm{n}^{\circ} 1$, pp. 21-26.

. (2008), "Americanidade/Americanização" (2008) (text available on line at: http://partnership.files.wordpress.com/2008/02/americanidade-e-americanizacao.pdf. 
CANTY, D. (1996), "Le jeu d'imitation dans Copies conformes de Monique LaRue", vol. 21, n 2 , pp. 324-336.

DUPONT, L. (1991), "L'américanité québécoise ou la possibilité d'être ailleurs", in Dean Louder (ed.), Le Québec et les cultures de Nouvelle-Angleterre, Québec, Presses de l'Université Laval, pp. 187-198.

ÉTIENNE, G. (1987), Uma mulher calada, trans. Zilá Bernd, Porto Alegre, Editora da Universidade du Rio Grande do Sul.

GENTZLER, E. (2008), Translation and Identity in the Americas: New Directions in Translation Theory, London and New York, Routledge.

GODBOUT, J. (1986), Une histoire américaine, Paris, Seuil.

. (1988), An American Story, trans. Yves St-Pierre, Minneapolis, University of Minnesota Press.

. (1999), Uma história americana, trans. Samira Lunes, Sāo Paulo, Nova Alexandria.

GUILLEMETTE, L. (2000), “Littérature québécoise et expérience continentale : américanité et/ou américanisation?", L’Action nationale, vol. 90, n 6, pp. 51-65.

HÉBERT, A. (1972), Kamouraska ou A Máscara da Inocência, trans. Leônidas Gontijo de Carvalho, Rio de Janeiro, Editora Civilização Brasileira.

. (1986), Os selvagens de Bassan, trans. Vera de Azambuja Harvey, Rio de Janeiro, Guanabara.

KLINKENBERG, J.-M. (1987), “Altérité et narcissisme chez Jacques Godbout. A propos de Une histoire américaine", in Carla Fratta (ed.), L'alterité dans la littérature québécoise, Actes du colloque de Bologne, 1986, Bologna, C.L.U.E.B., pp. 225-252.

LARUE, M. (1989), Copies conformes, Paris, Denoël. 
MORENCY, J. (2004), “L'américanité et l'américanisation du roman québécois. Réflexions conceptuelles et perspectives littéraires", Globe : revue internationale d'études québécoises, vol. 7, ${ }^{\circ}$ 2, pp. 31-58.

POULIN, J. (1984), Volkswagen Blues, Montréal, Québec/Amérique.

VAN SCHENDEL, N. (2001), "Une américanité de la francophonie? Les perceptions des migrants québécois" in Donald Cuccioletta (ed.). L'Américanité et les Amériques. Québec: Presses de l’Université Laval, pp. 193-224.

Recebido em 30/08/2012 Aceito em 30/10/2012 